University at Buffalo School of Law

Digital Commons @ University at Buffalo School of Law

2013

\title{
Legal Tails: Policing American Cities through Animals
}

Irus Braverman

University at Buffalo School of Law, irusb@buffalo.edu

Follow this and additional works at: https://digitalcommons.law.buffalo.edu/book_sections

Part of the Criminology Commons, and the Law Commons

\section{Recommended Citation}

Irus Braverman, Legal Tails: Policing American Cities through Animals in Policing Cities: Urban Securitization and Regulation in a 21st Century World 130 (Randy K. Lippert \& Kevin Walby, eds., Routledge 2013)

This is an Accepted Manuscript of a book chapter published by Routledge in Legal Tails: Policing American Cities through Animals on 7/19/2013, available online: https://www.routledge.com/Policing-Cities-Urban-Securitizationand-Regulation-in-a-21st-Century/Lippert-Walby/p/book/9780415540339.

\section{C. ${ }_{\text {COPYRIGHT }}^{\text {N }}$}

This Book is brought to you for free and open access by the Faculty Scholarship at Digital Commons @ University at Buffalo School of Law. It has been accepted for inclusion in Contributions to Books by an authorized administrator of Digital Commons @ University at Buffalo School of Law. For more information, please contact lawscholar@buffalo.edu. 


\section{Legal Tails \\ Policing American Cities through Animals}

\section{Irus Braverman}

Today, through our ideologically loaded narratives of their lives, animals "hail" us to account for the regimes in which they and we must live. We "hail" them into our constructs of nature and culture, with major consequences of life and death, health and illness, longevity and extinction.

---Haraway 2003: 17

Armed with a baton, Chief Officer Michael Armatys cautiously walks to the back of the house and then toward the barking dog. "Hi doggie, good boy," he says reassuringly. The dog, for his part, is unconvinced. He seems ready to leap free of the flimsy rope that ties him to the tree. I keep a safe distance, just in case the rope doesn't hold. While doing so, I notice the body of a dead bird on the ground, a rugged mailbox barely screwed to the house overfilled with mail, tons of peeling white paint, and a few neighbors that have come out to watch the show. One of the neighbors shouts to us, "They come only at night, and the dog is out in the sun all day." Officer Armatys looks around one last time and then heads back toward the side door, where I am standing. "Will you seize the dog?” I ask. "Well, it's officer discretion,” he says. "If the dog was hot and panting back there then it would be a no brainer: we would take the dog." "Although he had some water in a little container, the shelter is inadequate," he continues to explain as he tags a notice on the doorknob. "ESPCA: NOTICE TO COMPLY," reads the top of the notice in bold letters. A yellow highlighter marks that this is a violation of Article 26, Section 353-B of New York State’s Agriculture and Market Law.

We are in East Buffalo, a decaying urban neighborhood rife with abandoned houses. Officer Armatys-short, bulky, and dressed in a blue-and-white uniform adorned with badges and protected by a bulletproof vest—-knows his way around the city's neighborhoods, pointing out the houses he has visited in the past. He has been doing this since 1973, he tells me proudly. Over the years, he has dealt with thousands of animal abuse cases, made hundreds of arrests, 
and rescued thousands of animals. "As New York State peace officers," he explains, "we have the power to make an arrest and the power to execute search warrants." Still, "we try to work closely with the police department, and the fire department, and child protection," Armatys tells me. "It's all related, if they are going to beat an animal they are definitely going to beat a spouse. You see that a lot.” Bald eagles, red-tail hawks, alligators, and even elephants-Officer Armatys has indeed seen it all. Yet at the end of the day, it is not these animals that concern him the most. "I don't worry about the four-legged animals," he explains. "It's the two-legged animals I am concerned about.”

Likewise, this chapter's concern is not so much with four-legged animals as with the stories that they relay about how two-legged animals are policed in U.S. cities. Specifically, it is concerned with the role of animals in governing humans in urban space. In this sense, the story of policing animals in the city reveals aspects of policing humans. Although legal norms often contain assumptions about human agency, they just as often have assumptions about the lack of agency on the part of the animals they purport to protect. As a result, the project of policing animals does not target animals directly. Rather, it is performed through the regulation of humans. Moreover, although seemingly enacted to control animals, animal laws and ordinances are very much a way to monitor and control the conduct of humans. In the city, human-animal relations are expressed, regulated, and surveilled more closely than anywhere else. Such regulations and systems of surveillance define not only the limits of human conduct, but also the limits of the city itself. The "hailing" Donna Haraway refers to in this chapter's epigraph is the call that forms the subject-in this case, an animal subject whose non-humanity is already assumed, that is hailed through its regulation in urban space.

I interviewed Officer Armatys twice, the first time at his office in Erie County's Society for the Protection of Animals (SPCA). Established in 1867, this local branch of the SPCA is the 
second oldest nonprofit organization in the country. A few months later, I joined him for a ridealong in the city for what he called a "routine workday." Additionally, I interviewed Erie County’s SPCA executive director Barbara Carr, SPCA's Chief Investigator Lindsey Styborski, the organization's Wildlife Administrator Joel Thomas, Director of Animal Control for the City of Buffalo in the Department of Public Works Kelly McCartney, and Buffalo's City Clerk Jerry Chwalinski. In addition to these interviews, this chapter considers the laws and ordinances of both New York State and the City of Buffalo. I draw on these sources to convey a story about how the City of Buffalo polices its nonhuman and human population, what I refer to as "legal tails." The complexities of human-animal interactions are illustrated here through anecdotes that expose the material interactions between humans and animals in the city.

In previous work, I have written about the management of various types of animals in the city. My book Zooland: The Institution of Captivity (Braverman 2012d) identifies certain technologies through which animals are known, reproduced, regulated, and — more generallygoverned by contemporary North American zoos, which have evolved in cities. My other work (Braverman 2012a; 2012b) has explored how laws categorize animals in ways that attempt to capture their mobility and impose order upon them and how these laws are resisted and mobilized to reflect the fluidity of these constructs. In this chapter, my focus is on the establishment and enforcement of dog laws in the city and on what such dog laws teach us about the regulation of humans in urban space. Even as they pertain specifically to the laws of New York State and the City of Buffalo, the insights obtained here are relevant to many U.S. cities.

\section{Companion Animals in Contemporary United States}

The animal studies literature refers to the large mass of nonhuman animals in cities as a "shadow population" or a "subaltern animal town" (Wolch 1995: 736). Although these 
references are markedly true of wild, pest, laboratory, and farm animals in the city (Braverman 2012a), they seem outdated and perhaps even irrelevant with regard to companion (or pet) animals. Walking on the streets of any American city, one cannot but notice the ubiquitousness of pets. I dare suggest, moreover, that the thriving state of pets in the city, alongside the annihilation of all other nonhuman animals from this space, is what quintessentially defines the modern city vis-à-vis the country or rural society (in the United States, at least). Expelling farm animals to the country and replacing work animals with machines have been central to the making of the postindustrial city. Although pets are by no means confined to city spaces, they have nonetheless flourished in urban settings and, in this sense, have become a distinctly urban phenomenon. Integral to the average modern urban household in the United States, these animals also provide a justification for forms of policing that take place in the intimate and constitutionally protected setting of the home. Through their pets, human owners are subject to various forms of regulation, including an insistence on licensing and proper care.

Dogs in particular are increasingly a fundamental part of the American family. In August 2011, approximately 78.2 million people owned dogs in the U.S. (Humane Society of the United States 2012). ${ }^{1}$ The total expenditure for pets in the U.S. in 2012 is estimated at $\$ 52.87$ billion, more than the gross domestic product of many countries (Manning, CNS news 2012). Pet health insurance also has become common, as is malpractice insurance for veterinarians, partly fueled by the success of legal arguments that companion species cannot be valued as ordinary property (Haraway 2008: 52), a point I consider below. Moreover, a recent survey commissioned by Milo's Kitchen ${ }^{\mathrm{TM}}$ and publicized in "Business Wire" reveals that 81 percent of Americans consider their dogs equal members of the family, while 77 percent own up to talking about their pups as if they are human family members (Business Wire 2011). The survey also shows that 54 percent of Americans consider themselves to be "pet parents" instead 
of "pet owners" and that, in fact, 58 percent of American dog owners are comfortable calling themselves nicknames such as "Mommy" and "Daddy" when referencing their dogs and 35 percent even refer to their dog as "son" or "daughter." The following sections consider the role of law in regulating these dogs and other companion animals and, through these animals, in policing humans in American cities.

\section{Companion Animals and the Law}

Whereas a large and growing literature is dedicated to studying direct forms of policing of human populations in the city, little has been written about the regulation of humans through policing animals in this space and about the relations between these two forms of policing. I have previously argued that laws order the messy materialities of animal-human life into neat classificatory schemes (Braverman 2012a). Animals provide an immense challenge to law's imperial classification project. In no place is this more apparent than in the city. It is in the city that law attempts to civilize nature, which by definition cannot be civilized. The first and foremost project in the regulation of animals is their classification into distinct legal categories defined by their relationship with humans.

The vast majority of the animal kingdom falls into some or all of the following legal orders: wild, domestic, agriculture, pests, and laboratory animals. Each category represents a particular set of human-animal relationships that translates into specific temporalities and materialities. The city is partly defined by the particular animal-human relationships that are permitted within its territories. Most strikingly, agricultural animals are out, pets are in. This, then, is the city's civilizing mission: to house, control, even manufacture such animals that in turn may provide a safe mirror to man's otherness and proof of his humanity, while simultaneously proving man’s domination over animals and nature.

Animal categories are not always consistent; they change through time and space 
(Braverman 2012a: 9). City by city and state by state, laws differ about whether and how animals may be privately kept in urban environments. Specifically, animal laws define entire animal kingdoms according to the level of legal protection that they are afforded from humaninflicted harm (Douglas 1966). Every animal is classified as either "protected" or "unprotected," prescribing the legal actions humans may or may not direct at the animal and its environment. Although protected wild animals cannot be confined to "wilderness" areas nor excluded from cities, they are nonetheless prohibited from entering into the private urban home. By contrast, pets are welcome inhabitants in the urban household and receive legal protections as city dwellers. Animal Geography scholars Jody Emel and Jennifer Wolch explain along these lines that invisible lines "historically divided the animal world into those worth protecting because they were seen as either part of nature (wildlife) or the human community (pets), and those not worth protecting because they were neither (farm animals) and constituted sources of profit and value" (Wolch and Emel 1998: 14). Whereas the city is the quintessential home for animal pets, the country is the only place for farm animals.

In Buffalo, New York, the Animal Control Agency is responsible for enforcing laws that protect humans from pets in the city, and the ESPCA enforces animal protection laws, namely laws that protect animals from humans. Such latter protections include Title 18, Chapter 3 of the federal U.S. Code, which governs crimes against animals, birds, fish, and plants. In New York State, Sections 350 through 377 in Article 26 of the New York Agriculture and Markets Law protect certain animals in the city through the following non-exhaustive list of prohibitions: animal fighting; overdriving (overworking), torturing and injuring animals; failure to provide proper sustenance; failure to provide appropriate shelter for dogs left outdoors; prohibitions regarding confinement of companion animals in vehicles in extreme temperatures; prohibitions against the abandonment of animals and against throwing 
substances injurious to animals in public places; and prohibitions against clipping or cutting the ears of dogs, dog stealing or removing, and seizing or transporting dogs for research purposes (N.Y. Agric. \& Mkts. Law \$350- 377). Although dogs are defined as human property, legal prohibitions make clear that dog owners cannot do with them as they please, even in the confines of their own home.

Historically, domestic animals were farm and working animals and were recognized to have "intrinsic value" under common law (Frasch 2011). In many instances, courts refused to expand the term to include pets, which were assumed to lack intrinsic value (Commonwealth $v$. Massini). ${ }^{2}$ Today, the Code of Federal Regulations (CFR) defines "pet" as: “[A]ny animal that has commonly been kept as a pet in family households in the U.S., such as dogs, cats, guinea pigs, rabbits, and hamsters. The term 'pet' excludes exotic animals and wild animals" (9 C.F.R. \$1.1.). New York State regulations are clearer but still circular in defining a pet as "any domestic animal that has been adapted or tamed to live in intimate association with people but is not limited to, dogs, cats, rodents, fish, birds, snakes, turtles, lizards, frogs and rabbits" (N.Y. Gen. Bus. Law $\$ 750-a)$. The definition of pets through their companionship with humans allows extension of these legal norms to more and more animal species that enter the city under the rubric of "pet" animals, thus prescribing their protection from humans and legitimizing the policing of owners' homes and backyards.

Alongside dogs and cats, birds, reptiles, amphibians, and other animals have been defined as companion animals, thereby paving the way for their legal entry into the city. For example, in People v. Garcia (2006), a New York court held that a goldfish was a companion animal under an anti-cruelty statute. In that case, the boy who owned the goldfish regularly attended to it and even named it after himself. ${ }^{3}$ The court defined the legal category of this animal based on the particular human-animal relationship that had developed. Courts have also 
considered various characteristics of the animal, such as the duration of its captivity and its training and behavior, to find that a monkey was a domesticated pet, in one instance (City of Rolling Meadows v. Kyle), but that a pet monkey was a wild animal under a rabies control statute because monkeys are not a "common domestic species," in another instance (Keeble v. Cisneros).

Whereas criminal law has made strides in addressing animal cruelty, as reflected in the detailed norms described later in this chapter, pet owners face an uphill battle in the civil arena. When a human is injured or killed due to the intentional or negligent act of another, that individual usually has the right to sue the responsible party for damages and acquire legal compensation for an injury. Yet despite the importance that urban society in the United States attaches to pets, these same remedies are often unavailable for injury to these animals. In the U.S., as in many other common law countries, pets are considered the personal property of the owner and have no independent standing in courts (Wisch 2003). As a result, when a pet is injured or killed, it is the owner who must file a lawsuit to recover damages. For the most part, the traditional computation of damages for the loss of a pet is the pet's market value-the monetary sum someone else would pay for the identical pet of the same age, breed, and condition. Because most companion animals are not pedigreed or are of mixed breed, they have little or no market value. Thus, their owners are often left with no compensation.

However, U.S. courts are increasingly grappling with the possibility of awarding damages for loss of the pet's companionship and for the emotional distress suffered by the owner (ibid.). Whereas the majority of states still reject such damages for various reasons, a few states have broken away from traditional private property notions, providing recovery for these nonhuman household members. Alaska, Florida, Hawaii, Idaho, Kentucky, New York, New Jersey, and the District of Columbia have expressed a willingness to accept claims requesting damages beyond market value (ibid.). Causes of action for emotional distress, loss of 
companionship, and, on a more limited basis, damage to the "intrinsic value" of the pet are becoming increasingly common, thereby strengthening the unique status of the pet in the city.

In Corso v. Crawford Dog $\mathcal{E}^{\circ}$ Cat Hospital, a New York court considered the intrinsic value of pets under the law. There, an elderly woman brought a claim for damages after the animal hospital mishandled the euthanization and funeral arrangements for her pet poodle. Upon opening the casket for a last goodbye, she found the body of a dead cat, rather than her beloved dog. The court specifically distinguished a pet from other sentimental inanimate objects. "A pet is not just a thing but occupies a special place somewhere between a person and a piece of personal property," the judge reasoned. "To say it is a piece of personal property and no more is a repudiation of our humaneness. This I cannot accept" (Corso v. Crawford Dog \& Cat Hospital: 183). Legal scholars have even suggested that it should not only be incumbent upon the owner to recover for damages to their pets but that the animal itself should have standing, through a legal guardian, to bring a claim (Favre 2000). Such standing would allow the animal to receive damages for their injury, which will likely be awarded to a trust or other fund from which their care will be paid (Chute 2012).

Alongside the increasing remedies granted to pet owners, they are also subject to increased scrutiny in the form of detailed regulations that prescribe certain standards for care. This care includes matters such as proper shelter, restraints, licensing and identification, and medical treatments. In Buffalo, New York, such regulations pertain almost exclusively to dogs. The City Ordinance requires dogs over four months of age to be licensed, restricts the maximum allowable number of dogs to three for the entire premise, and obliges dog owners to physically prevent their dogs from leaving their premises, unless securely held on a leash. Finally, the City Ordinance establishes that "it shall be the duty of every dog owner or person having possession, custody, or control of a dog to remove any feces left by said dog on any 
property within the City of Buffalo and deposit the feces in a sealed container lawfully used for the disposal of refuse" (Buffalo N.Y., Code Chapter 78-19, Article IV). On the books, humans may bring certain animals into the city, but only under conditions of strict control so that these animals do not frighten fellow human dwellers and that their feces do not contaminate its streets.

Dog laws are not unique to New York State or to the City of Buffalo. Many other states also mandate rabies vaccinations with accompanying fees and certifications and require precise dog shelter design (Butler 2011). According to an Oklahoma statute, for example, dog breeders must provide at least the following for a dog's enclosure: "The mathematical square of the sum of the length of the dog in inches (measured from the tip of its nose to the base of its tail) plus 6 inches; divided the product by 144, times 2. Mathematically, the space the commercial pet breeder must provide for the first $\operatorname{dog}$ equals 2 x $[$ (length of $\operatorname{dog}$ in inches +6$) \mathrm{x}$ (length of $\operatorname{dog}$ in inches +6$) / 144]$ ] (Okla. Admin. Code $\$ 532: 15-3-3)$. Dog disposal is also heavily regulated by federal norms that define the proper ways to transport and sell dogs (7 U.S.C.A. \$2131). Again, human-dog relations are intensely regulated and policed to ensure the dogs' proper presence in cities under the strict guardianship — aka care—of their specific human owners.

\section{Walking the Beat: Enforcing Dog Laws in Buffalo, New York}

At least three agencies enforce the federal, state, and municipal legal norms that apply to companion animals in the City of Buffalo, New York: Buffalo's City Clerk, the City's Animal Control in its Department of Public Works, and the local SPCA branch. Article 7, Section 109 of the New York's Agriculture and Markets Law provides that, "The owner of any dog reaching the age of four months shall immediately make application for a dog license." The section also provides that the application for an annual license must be submitted to the city clerk and that, "The application shall state the sex, actual or approximate age, breed, color, and 
municipal identification number of the dog, and other identification marks, if any, and the name, address, telephone number, county and town, city or village of residence of the owner. . . The application shall be accompanied by the license fee ... and a certificate of rabies vaccination" (N.Y. Agric. \& Mkts. Law \$109). Section 111 adds that each licensed dog "shall be assigned, at the time the dog is first licensed, a municipal identification number. Such identification number shall be carried by the dog on an identification tag which shall be affixed to a collar on the dog at all times, provided that a municipality may exempt dogs participating in a dog show during such participation” (N.Y. Agric. \& Mkts. Law \$111).

Buffalo's City Clerk Jerry Chwalinski explains that his role in regulating animals is limited to licensing, suggesting that "the only reason we license dogs is to mandate people to get a rabies certificate." Chwalinski complains that although the annual license fee is only $\$ 13.50$ - "less than a visit to the zoo or a vet" - many people fail to apply. To deal with such recalcitrant behavior, every summer the City sends interns to comb its streets and detect unlicensed dogs. "They walk around equipped with the addresses of licensed people, looking for those unlicensed people who are playing with dogs in their backyards," Chwalinski tells me. He explains the rationale behind the City's preoccupation with dog licenses: "We want to make sure that the people are indeed the owners-it's the law." "We manage to catch hundreds of unlicensed dogs every year," he concludes proudly. ${ }^{4}$ Thus, the only way for animals to lawfully dwell in the modern city is under the designation of companion species. The city, for its part, enforces this relationship to the letter: through the application of licensing and identification requirements, the city ensures that each and every dog has an owner.

But such efforts of controlling both nonhuman and human populations are often frustrated. "Unfortunately, I would have to say that 90 percent-if not higher-of the dogs that we take in are unidentified dogs," says Director of Animal Control Kelly McCartney in an 
interview. As a result, the City has no means for finding their human owners. "Dogs sit here without their owners ever reclaiming them," McCartney says. She explains that the Animal Control shelter receives approximately 3,500 dogs per year. "We bring in strays, seizures, raids, whatever the case may be, and these dogs are held for a minimum of 72 hours, after which they become the property of the City. If they pass an assessment by a behavioralist, they go up for adoption.” After a dog sits in the shelter for over four weeks without being adopted, it is transferred to the SPCA or to one of the different dog rescue groups and coalitions that operate in the city. ${ }^{5}$ Dogs are allowed back into the City of Buffalo only when claimed by a human who assumes the responsibility for their care.

Along the same lines, stray dogs are deemed dangerous and are not tolerated by the City of Buffalo. McCartney tells me that six officers are in charge of enforcing "the ordinances of the City of Buffalo to basically protect the people from dangerous dogs roaming at large, unlicensed dogs, nuisances, quality of life issues, that sort of thing." She further explains how a dog may be deemed "dangerous" and the ensuing procedures:

If somebody were to be bitten by a dog and were to seek medical treatment, or the dog control officers were on the scene or were at least called to the scene, then of course we tell those people that they have an option to file a "dangerous dog" report. So the dog control officers are in court with the dangerous dogs, where a Special Term Judge would then determine the disposition of that dog.

"It's very, very seldom that a judge would deem an animal for euthanasia," McCartney emphasizes, making it abundantly clear that the City does in fact have such powers.

Another means of dog control-namely, of ensuring that each and every urban dog has a specific human caretaker-is the City Mayor's Complaint Line. McCartney explains: 
[A]nybody in the city limits can call, and if they have a complaint about ... an animal or unlicensed dogs, they put those in and those are printed out on a daily basis and dispatched to the Dog Control Officers depending on districts. The Dog Control Officer visits every single address and checks out the situation and either tickets, gives warning-or, in some instances, depending on the condition of the animals will remove them. So that's another means of dog control. The phones are constantly ringing and there's also the police radio (ibid.).

The City's Dog Control Officers enforce the classification of animals in the city: only pet animals are allowed into the city; as such, they must be coupled with a human caretaker and dwell in a human home; and upon their departure from this home, they are no longer considered to be legal urban dwellers and must temporarily be managed by the city, until it finds them a new human home.

Alongside the exclusion of dogs without owners from Buffalo's streets, specific New York laws enforce certain conduct pertaining to the dogs' management within the home. Article 26, Section 371 of the New York State Agriculture and Markets Law authorizes peace officers to summon or arrest any person that perpetuates an act of cruelty upon an animal protected under the law (N.Y. Agric. \& Mkts. Law \$371). In Massachusetts and New York, agents of humane societies and associations are appointed as special officers and are authorized to enforce statutes outlawing animal cruelty (Arluke 2004). Erie County's SPCA is the largest local organization in New York State. Three of its officers are authorized to act as peace officers for the enforcement of animal cruelty laws in the City of Buffalo and its surroundings.

Chief Officer Armatys of the ESPCA is one of the three peace officers. He believes that many animal abuse cases are intertwined with criminal conduct toward humans, implying the broader importance of policing human-animal relations in the city. Officer Styborski states 
more explicitly: "We see the correlations between animal and human abuse. First comes bedwetting, then animal abuse, and, finally, burglary and murder" (interview). Human-animal relations are thus thought to serve as early indicators for future criminal conduct toward humans. Because criminal conduct toward animals is often linked with criminal activity that is unrelated to animals, such as illegal betting and drug use, it often necessitates cooperation among various policing agencies. Officer Armatys uses organized dogfights as an example for this type of cooperation. "The organized stuff is really hard to get a handle on because, naturally, you are not going to be invited in. They move all the time, and it's big money for betting," he explains. "There is narcotics, firearms, or some kind of weapons at these fights. That's why, if we are busting somebody, it is always handy to have some kind of police action with you" (Armatys, interview). This story demonstrates how animal police and human police work together to enforce laws protecting both humans and nonhumans. The following example highlights that, similar to many other crimes, the causes of animal abuse are complex, and that family histories and social and economic contexts play an important role in their trajectories.

[O $]$ ne time I had a complaint in the City of Buffalo's Eastside about a dog who was short chained to the fence in the hot sun and all that. So I roll up and I see this dog, and the owner comes out of the house and he was kind of irate. I said, "Look, we had a call about this dog here. He is in the hot sun, short chained, he can't move." I said, "He has no water." He was a good looking pit-bull. I said: "You have to move the dog to a secure area... Put him in the house or the backyard or the shade where there is water." So he did that. I asked, "Let me see some identification." So he gives his driver's license and I'm writing down his name and I look at his last name and I say, "Don't I know you?" He says, “No, you don't know me.” And I said, “Did I arrest you for something some 
time back?” And he said “No.” And I said, "Didn’t I arrest you for dog fighting?” He looks at me with a big smile and says, "No, you arrested my dad" (Armatys, interview). But dog and cockfights are still the extreme and rare cases of human-animal crimes in the city. More often, Armatys' job is to educate the public about how to properly care for their animals. In these everyday instances, the enforcement of humane law toward animals often bumps up against human prejudices toward other humans. For example, neighbors will use animals as a way to infer racial statements. Armatys tells me that he once received a complaint about Sudanese residents on Buffalo's West Side. In his words,

The way the call went out it said, "Children abusing a cat is occurring right now." So I happened to be in the area and swung by. [T] he guy that made the complaint was white and the kids were black. These kids were sitting there with a string and all they were doing was playing with the kitten. So I talked to the adults and I went to question them and the kitten was fine, there was no problem. The kids were being cared for, too. So I looked at the guy and I said "Really." He just went back into his house (Armatys, interview).

Animals, humans, race, class, and crime - all play a role in animal law enforcement in the city. The city's density - both in terms of physical space and in terms of population size and location-provides fertile grounds for policing human-animal and human-human relations, which then manifest in particular forms of urban laws and regulations.

The regulations that define the place of animals as pets also perform an important role in determining the division between the country and the city. Recently, the ESPCA has been investigating an unusual case of animal hoarding by what one ESPCA officer labeled "a rich girl who just thinks she is entitled to do anything." "She had seventy-three horses, fifty-three cats, and four dogs," says one of the ESPCA officers. "And the [animals] were living in squalor. 
There wasn't an inch that wasn't covered in waste, and everything there had feces everywhere, and no food, no water." After a veterinarian examination, one horse had to be euthanized. The woman-Beth Lynne Hoskins-was charged with 125 counts of misdemeanor animal cruelty. On May 21, 2012, a nonjury criminal trial on animal abuse got under way in New York's Aurora Town Court. Unsurprisingly, the opening statements received much press. "This is a case of animal abuse by neglect," the Assistant District Attorney said, later ticking off all the horses' names. The Defense Attorney denied this categorization: "It is a breeding farm. Horses are bred and fed. They are like cows, livestock. They are not like dogs or cats" (Buffalo News 2012). Such legal arguments reveal the importance of animal classification for defining permissible and impermissible human conduct. While the ESPCA's individual naming of the horses purports to treat horses and dogs on equal grounds and implies the extension of the legal protections afforded to dogs onto horses, the adverse party's claim is that pet laws should not apply to farms or, in other words, that the country is not the city.

\section{Conclusion}

Citizenship across species ties many knots, none of them innocent.

---Haraway 2008: 118.

Legal stories about companion animals_especially dogs_-illuminate aspects of policing in the American city that are often invisible in direct stories of human policing. In this sense, dog laws have more than cuddly and furry tales to tell. Such tales expose the underlying classificatory schemes that distinguish pet dogs from farm horses. Alongside their illumination of overlooked human-animal relations, these stories also reveal hidden aspects of law's "humane" enforcement. We learn that while some animals—-such as wild geese-are allowed to temporarily pass through the city, not all animals are welcome as permanent residents of this space. Animal laws instruct us which animals are allowed into the city and under what conditions. More than regulating the everyday of urban life as it pertains to animals, humans, 
and the interrelations thereof, such laws and their enforcement help define the very essence of the city. Through its distinct matrix of animal-human relationships, the city is distinguished from its significant other, "the country," where a different set of animal-human relations takes place.

I have shown how certain laws protect humans from specific dogs by identifying them as "dangerous animals" and how other laws grant powers to city clerks to identify and license all dogs in the city, ensuring that every dog has a registered human owner. These clerks have the power to roam city streets, looking for human offenders who have taken the liberty of caring for unlicensed dogs. A hotline system enables telephone calls about stray dogs and other nuisances to flow into the City's switchboard, triggering the dispersal of Dog Control Officers. These officers collect such problematic dogs into their shelters for screening and then release them back out again into the city, this time to more adequate homes. Meanwhile, cases of animal abuse and cruelty are dealt with by a small workforce of nongovernmental officials, who work closely with the City's police and the public to enforce these norms. Such bits and pieces of legal tales reveal not only the detailed policing of the interrelations between humans and animals that occurs in the city but also the importance of such policing for the definition of this space. At the end of the day, whether one has created a proper shelter for her dog is a question of legal geography, enforced on both humans and nonhumans in and through the city. 


\section{References}

Animal Service League (2012) Animal Service League. Online. Available HTTP: <http://www.animalserviceleagueny.org/> (accessed 29 May 2012).

American Pet Products Association, Inc. (2012) APPA National Pet Owners Survey. Online. Available HTTP: <http://www.americanpetproducts.org/press_industrytrends.asp> (accessed 2 May 2012).

Arluke, A. (2004) Brute Force: Policing Animal Cruelty. Indiana: Purdue University Press.

Braverman, I. (under review) (2012a) 'Animobilities and Mobilegalities,' Humanimalia: $A$ Journal of Human-Animal Interface Studies.

---(under review) (2012b) 'Animal Frontiers: A Tale of Three Zoos in Israel/Palestine,' Cultural Critique.

---(2012c) 'Foucault Goes to the Zoo: Zooveillance in North America,' Surveillance \&o Society $10(2): 119-133$.

---(2012d) Zooland: The Institution of Captivity, Stanford: Stanford University Press.

Buffalo Humane (2012) Buffalo Humane. Online. Available HTTP: <http://www.buffalohumane.org/> (accessed 29 May 2012).

Buffalo News (2012) 'Contrasting Views as Hoskins Trial Opens.' Online. Available HTTP: < http://www.buffalonews.com/city/police-courts/ courts/article867302.ece> (Accessed May 21, 2012).

Business Wire (2011) New Study Reveals That the American Family Has Gone to the Dogs: More Than 8 in 10 Pet Parents Say Their Dogs are an Equal Member of the Family.' Online. Available HTTP: <http://www.businesswire.com/news/home/ $20110502006312 /$ en/Study-Reveals-American-Family-Dogs $>$ (accessed 2 May 2011 ). 
Butler, W. (2011) Welcoming Animals Back to the City: Navigating Public Health Tensions of Urban Livestock to Achieve Healthy and Resilient Communities, Working Paper Series, Fla. St. Univ.

Callon, M. (1986) 'Some Elements of a Sociology of Translation: Domestication of the Scallops and the Fishermen of St Brieuc Bay,' in J. Law (ed.) Power, Action, and Belief: A New Sociology of Knowledge, London: Routledge.

Chute, L.A. (2012) 'Helping Animals Stand on their Own Four Feet: The Inadequacy of Current Legal Rights and Standing for Animals in New York State,' unpublished seminar paper (on file with author).

Douglas, M. (1966) Purity and danger: an analysis of concepts of pollution and taboo, New York: Praeger.

Favre, D. (2000) 'Equitable Self-Ownership for Animals,' 50 Duke L. J. 473: 501, 502.

Frasch, P., Hessler, K., Kutil, S., and Waisman, S. (2011) Animal Law in a Nutshell, St. Paul, MN: West Publishing.

Haraway, D. (2003) The Companion Species Manifesto: Dogs, People, and Significant Otherness, Chicago: Prickly Paradigm Press.

--- (2008) When Species Meet, Minneapolis: University of Minnesota Press.

Herbster, A. (2000) 'More than Pigs in a Parlor: An Exploration of the Relationship Between the Law and Keeping Pigs as Pets,' 86 Iowa L. Rev. 339.

The Humane Society of the United States (2012) U.S. Pet Ownership Statistics. Online. Available HTTP: <http://www.humanesociety.org/issues/pet_overpopulation/facts/pet_owner ship_statistics.html> (accessed 22 May 2012). 
--- (2012) 'Shelters.' Available HTTP: <http://www.humanesociety.org/animal_community /resources/qa/common_questions_on_shelters.html\#How_many_animals_enter_anim al_shelters_e>

Huss, R. (2003) 'Separation, Custody, And Estate Planning Issues Relating to Companion Animals,' 74 U. Colo. L. Rev. 181.

Manning, S. (2012) 'Americans Spent Nearly \$51 Billion on their Pets in 2011,' Cnsnews.com. Online. Available HTTP: <http://cnsnews.com/news/article/americans-spent-nearly51-billion-their-pets-2011> (accessed 2 March 2012).

Merriam-Webster (2012) Merriam-Webster Dictionary-Encyclopedia. Online. Available HTTP: <http://www.merriam-webster.com/dictionary/speciesism> (accessed 30 May 2012).

Ontario Veterinary Medical Association (2012) Pets: An Integral Part of the Family. Online. Available HTTP: <http://www.ovma.org/pet_owners/ownership_benefits/part_of_ family.html> (accessed 29 May 2012).

Pet Food Manufacturers Association (2011) Pet Population. Online. Available HTTP: <http://www.pfma.org.uk/pet-population-2011/> (accessed 29 May 2012).

Posh Puppy Boutique (2012) Posh Puppy Boutique. Online. Available HTTP: <http://www.poshpuppyboutique.com/aboutus.asp> (accessed 27 May 2012).

Steere, A. (1994) 'Lyme Disease: A Growing Threat to Urban Populations,' Natd. Acad. Sci. USA 91: 2378-83.

Thomsen, M. (2010) 'Pets Around the World: China.' Online. Available HTTP: <http://www.petside.com/article/pets-around-world-china> (accessed 29 May 2012).

Wisch, Rebecca F. (2003) Quick Summary of Pet/Companion Animal Damages. Animal Legal and Historical Center, Michigan State University. Online. Available HTTP: 
<http://www.animallaw.info/topics/tabbed\%20topic\%20page/spuspetdamages.htm> (accessed 23 May 2012).

Wolch, J., and Emel, J. (1998) Animal Geographies: Place, Politics, and Identity in the NatureCulture Borderlands, London: Verso.

Wolch, J., West, K., and Gaines, T. (1995) 'Transspecies Urban Theory,' Environment and Planning D: Society and Space 13(6): 735-60.

\section{Cases Cited}

City of Rolling Meadows v. Kyle, 494 N.E.2d 766 (Ill. App. Ct. 1986).

Commonwealth v. Massini, 188 A.2d 816 (Pa. Super. Ct. 1963).

Corso v. Crawford Dog \& Cat Hospital, 415 N.Y.S. 2 d 182 (Civ. Ct. 1979).

People v. Garcia, 812 N.Y.S.2d 66 (N.Y. App. Div. 2006).

Keeble v. Cisneros, 664 F.Supp. 1076 (Tex. 1987).

\section{Statutes Cited}

9 C.F.R. $(2012) \S 1.1$.

7 U.S.C.A. $(2011) \S 2131$.

18 U.S.C.A. $(2011) \S 41-49$.

Buffalo N.Y., Code Chapter 78-19, Article IV (2005), available at

<http://www.city-buffalo.com/files/1_2_1/CityClerk/Ordinances/Article 3.pdf>

(accessed 29 May 2012).

N.Y. Agric. \& Mkts. Law (2011) §109 ch. 69, art.7.

N.Y. Agric. \& Mkts. Law (2011) \$111 ch. 69, art. 7.

N.Y. Agric. \& Mkts. Law (2011) §350- 377 ch. 69, art. 26. 
N.Y. Agric. \& Mkts. Law (2011) §371 ch. 69, art. 26.

N.Y. Envtl. Conserv. Law (2011) §11-0107.

N.Y. Gen. Bus. Law (2011) § 750-a.

Okla. Admin. Code (2011) § 532:15-3-3.

S.C. Code Ann. (2011) § 47-5-60.

\section{Interviews Cited}

Armatys, M. (10 Oct. 2011) Chief Officer Erie County SPCA, Buffalo, New York.

Armatys, M. (17 May 2012) Chief Officer Erie County SPCA, Buffalo, New York (Ride-along).

Carr, B. (5 Oct. 2011 ) Director, Erie County SPCA, in Buffalo, New York.

Chwalinski, J. (23 May 2012) Buffalo City Clerk (Telephone).

McCartney, K. (14 Oct. 2011) Director of Buffalo Animal Control, Department of Public Works, City of Buffalo N.Y. (Telephone).

Styborski, L. (13 Oct. 2011 ) Chief Investigator, Erie County SPCA, in Buffalo, New York.

\section{Notes}

1 According to a 2012 survey, 62 percent of U.S. households owned a pet (APPA), in comparison to 50 percent in Canada and Britain, and 15 percent in China (Ontario Vet. Med. Assoc. 2012).

${ }^{2}$ See, e.g., Commonwealth v. Massini, where the court refused to expand an animal cruelty statute beyond the precise wording of the statute: "equine animal, bovine animal, sheep, goat and pig."

${ }^{3}$ In this case, the defendant stomped to death the pet goldfish of a nine year-old boy. The Court found that child's pet goldfish was a "companion animal" under the statute, thereby convicting the defendant of aggravated cruelty to animals in violation of the Agriculture and Markets Law $\$ 353 \mathrm{a}(1)$.

${ }^{4}$ Incidentally, although we have never owned a dog, in summer 2011 we received a series of official notices indicating that the city had evidence we had an unlicensed dog. After the third notice my partner accused the city of harassment and the notices ceased to appear.

5 The Humane Society of the United States estimates that animal shelters care for six to eight million dogs and cats annually in the U.S., of whom approximately three to four million are euthanized. Local humane societies, Societies for the Prevention of Cruelty to Animals (SPCAs), and other animal protection organizations urge people to neuter their pets and adopt animals from shelters instead of purchasing them from breeders or pet stores (Humane Society, "Shelters" 2012). 